\title{
A VUELTAS CON LOS OBISPOS DE PAMPLONA DE ÉPOCA VISIGODA. APOSTILLAS A UNA RÉPLICA
}

\author{
POR
}

\author{
Koldo LaRrañaga Elorza
}

Universidad del País Vasco, Gasteiz-Vitoria

\section{Resumen}

El trabajo, que reincide en tema tratado ya antes por el autor en esta revista, se ocupa en lo esencial de responder a las críticas formuladas por $J$. J. Larrea a ese su anterior pronunciamiento sobre la cuestión. Este supeditarse a un guión impuesto por otro no empece, con todo, a que en el artículo resalten más nítidos y mejor explicitados algunos aspectos de la posición del autor, que en la toma de contacto previa pudieron quedar no suficientemente elucidados. En cualquier caso, de lo que no cabría dudar es de que esta discusión ayuda a centrar, no sólo el tema de la suerte que cupo al obispado de Pamplona en la etapa visigótica, sino también el de la situación derivada en el entorno circumpirenaico occidental durante la Antigüedad Tardía.

\begin{abstract}
This paper takes up again a matter that was already the subject of another article by the author in this review, and its aim is basically to answer the objections raised by J. J. Larrea against that first explanation of the matter. In spite of its restriction to an outline imposed by another, the article is, however, useful to bring out and make explicit some aspects of the author's thought, that perhaps were not sufficiently clarified and explained in his previous statement on the matter. In any case, this discussion is undoubtedly profitable to place correctly, not only the subject of the fate of the bishopric of Pamplona in the Visigothic period, but also that of the situation which arose in the western side of the circumpyrenean world during the Late Antiquity.
\end{abstract}


Convengo en que el tema no es de los que apasionan, y también en que pilla un pelín lejos al común de los mortales, para que uno se permita tanta insistencia sobre el mismo'. Pero, incluso a riesgo de abusar de la amabilidad de la Dirección y de la paciencia de los lectores, solicito un pequeño espacio adicional para atar algún que otro cabo suelto que, según conjeturo, ha debido quedar en mi anterior exposición sobre el tema, a juzgar por la respuesta que mi intervención ha merecido de J. J. LARREA ${ }^{2}$.

En nuestros diferentes enfoques del tema hay, según ha señalado muy bien mi estimado colega, cuestiones de matiz y una cuestión de fondo. No sé si merece la pena insistir sobre las primeras, porque se trata, por lo general, de lecturas diversas de unos mismos hechos, condicionadas en buena medida por la referida cuestión de fondo. Pero, toda vez que estamos en ello, diremos algo sobre las que se nos antojan de algún interés, siguiendo para ello el orden de presentación por puntos adoptado por mi colega.

1. J. J. LARREA se diría restar importancia ${ }^{3}$ al hecho de que una Iglesia se documente unas cuantas veces menos en los sínodos visigodos, habida cuenta, primero, de que se trata de asistencias producidas en un lapso de dos siglos, y, en segundo lugar, porque, al desconocerse la procedencia de los asistentes a determinados concilios, tampoco cabe llegar a fijar con certeza el número real de asistencias de una Iglesia. Pero, en cualquier caso, los datos están ahí: en la Tarraconense, la provincia más remisa de Hispania en cuanto a índice de asistencias a los sínodos generales, Tarazona - la que menos se deja ver en tales reuniones, si exceptuamos a Pamplona - documenta el doble de asistencias que ésta (6 contra 3), y, al igual que otras Iglesias de la Tarraconense, se halla también algo mejor representada en los sínodos provinciales (2 contra 1$)^{4}$. ¿Que eso apenas dice nada, y el "absentismo sistemático" (?) se produce sólo "en los 23 años que van de Toledo IV a Toledo X"? Es una forma de ver las cosas: forma de ver que, a nuestro modesto saber y entender, responde a un parti pris, como responden presumiblemente a partis pris otras formas de ver contrapuestas que puedan achacársenos. Convenimos con Larrea en las peculiaridades que se dan por lo común en la documentación antigua -escasa y

1 Cfr. J. J. LARrea: El obispado de Pamplona en época visigoda, en "Hispania Sacra" 48, 1996, 123-147; K. LARRAN̄AGA ElORZA: Sobre el obispado pamplones en época visigoda, en "Hispania Sacra" 49, $1997,279-317$.

2 De nuevo en torno a los primeros siglos del obispado de Pamplona, en "Hispania Sacra" 49, 1997, 319-326.

3 V. o. c., pp. 319s.

4 Nos basamos para hacer esta afimación en el hecho de que en el concilio egarense de 614 se hallan representadas 14 Iglesias de la provincia (es decir, todas, menos una). $O$ ihabrá que pensar que es Tarazona la que falta, o alguna de las otras que se revela más cumplidora por el resto, para contabilizar una asistencia más en el haber de Pamplona? V. nuestro art. anterior, p. 284. 
aleatoria, y que, por lo mismo, difícilmente puede llegar a ser estimada totalmente representativa de las realidades a que se remite, lo que hace que el argumento ex silentio haya de ser siempre bien sopesado, ni aplicado indiscriminadamente- Pero, dicho eso, convendrá conmigo en que en Historia se ha de trabajar sobre la base del material documental existente, y éste, entre otras cosas, dice que la comunidad cristiana de Pamplona no acredita la presencia de una sede episcopal en su seno hasta el año 589, y que esta sede - sin ser desde luego excepción al respecto, ni mucho menos ${ }^{5}$ - se revela especialmente remisa en el cumplimiento de las disposiciones conciliares sobre asistencia a sínodos. Ahora bien, si la regular y canónica presencia de los representantes de las Iglesias en los sínodos es el síntoma de que los lazos de la communio funcionan tal como deben, $y$, al contrario, la inasistencia de un número significativo de padres - provincias enteras en algún caso-- a los concilios generales toledanos es interpretada por lo común como la señal de graves problemas de unidad en el reino, el hecho de que una serie de Iglesias (las más occidentales de la Tarraconense) no den señales de vida en los sínodos provinciales durante largo tiempo (entre el sínodo provincial de Tarragona de 516 y el III general de Toledo de 589), o el que una Iglesia en concreto se muestre particularmente corta en sus presencias sinodales a lo largo de dos siglos, pueden de igual modo - y como hipótesis de trabajo, cuando menos-- ser interpretados como el síntoma de anomalías en el régimen de relaciones de tales Iglesias con sus coprovinciales y las del resto del reino. A esta persuasión se debe el que desde antiguo los autores que se ocuparon de la situación de la Iglesia de Pamplona en la etapa visigótica se hayan sentido obligados a buscar las causas de lo que estimaban anómala situación, hallándolas por lo general en las guerras de los Vascones contra los Godos ${ }^{6}$.

2. Opina Larrea que mi intento explicativo -a título hipotético, desde luego- de las ausencias de Huesca, Tarazona, Calahorra y eventualmente $\mathrm{Oca}^{7}$ y Pamplona en los concilios de la Tarraconense entre 516 y $542^{8}$ como reflejo de

5 V. lo que sobre asistencia de los obispos a los sínodos de la Iglesia goda escribe E. A. THOMPSON: Los Godos en España, Madrid 1971, pp. 49s y 323-326.

$6 \mathrm{~V}$, por ej., J. DE MORET: Investigaciones históricas de las antigizedades del Reyno de Navarra (1665), Pamplona 1765, pp. 159s; ID.: Annales del Reyno de Navarra (I. tomo, 1684), 5 vv., Pamplona 1766, t. I, p. 85.

7 No cabe olvidar que, al igual que en el caso de Pamplona, "el primer testimonio auténtico" que acredita la existencia de una sede episcopal en Oca es del año 589, y viene a ser la firma del obispo Asterius en las actas del III concilio de Toledo (v. D. MANSILLA: s. v. Burgos, dioc. de, en Q. aldea Vaquero, T. Marín Martínez, J. VIVes Gatell [dirs.]: Diccionario de Historia Eclesiástica de España, I, Madrid 1972, p. 290).

8 Sic, en lugar — pensamos- de 546. 
una "cierta situación de inestabilidad o de indefinición política en la zona" arranca del planteamiento de un "falso problema". Y le da pie a ello el ver que casos similares de inasistencias numerosas a sínodos se producen a la sazón en otras provincias eclesiásticas de España, citando al caso el sínodo de Valencia de 549, que reúne sólo a seis obispos y un arcediano, o el de Braga de 561, que reúne a ocho representantes de Iglesias frente a los doce que reunirá Braga II en $572^{10}$. Ahora bien, me pregunto cómo puede ser tildado de falso problema, sabiendo lo que en materia de asistencia a sínodos venían recalcando desđe Nicea los cánones conciliares, el que parte considerable de una provincia deje de asistir por largo tiempo a los sínodos de la misma. Si inasistencias prolongadas de una sola Iglesia a tales reuniones han sido motivo a menudo para que los estudiosos se hayan visto obligados a preguntarse por las circunstancias que determinaban las mismas (y con razón, habida cuenta de que no podía alegarse por sistema lo de la enfermedad del titular o la itineris longitudo y paupertas ecclesiarum, especificadas entre las eximentes por el III sínodo toledano de 589), ¿cómo no van a inquirir - a título hipotético, por supuestopor las que pueden explicar el que un grupo de Iglesias dejen de personarse por largo tiempo en las reuniones de su provincia? ¿Que se dan por entonces casos similares en la Hispania visigótica? Incluso dando por probado ser eso así (orillando de momento, sin embargo, lo de la similitud de las situaciones...), diremos que lo que procede en buena lógica no es negar el problema como tal, sino tratar de explicarlo en razón de las circunstancias peculiares que intervienen en cada caso. En conclusión, que nada de falsos problemas, sino a lo sumo problemas que requieren explicaciones o iluminaciones particularizadas en cada uno de los supuestos. Así, por ej., para las inasistencias que se producen en el sínodo de Valencia de 549 , a mí -muy poco versado, desde luego, en la historia de la provincia Cartaginense en la etapa visigoda - se me ocurre que las razones puedan hallarse en la situación de confusión y caos que vive el reino tras la desaparición - por muerte violenta- de Teudis en el 548, y de su sucesor Teudiselo, en el siguiente; y, por lo que hace al supuesto bajo índice de asistentes al sínodo bracarense de 561, puedo recordar que no faltan quienes, como E. FLÓREZ"1, argumentan justamente esa diferencia en el núnero de prelados presentes en Braga I y Braga II para afirmar la creación de nuevas sedes en el ínterim. Pero es que las situaciones en modo alguno pueden

9 Nos hemos permitido copiar nuestras propias palabras en el art. reseñado (p. 285). Mas véase, en cualquier caso, cómo ve ese periodo C. SÁNCHEZ ALBORNOZ: En torno a los orígenes del feudalismo, t. III: Los arabes y el régimen prefeudal carolingio. La caballería musulmana y la caballería franca del siglo VIII, 2. ed., Buenos Aires 1979, p. 46 nota 83.

10 De nuevo..., p. 320.

1 España Sagrada, IV, Trat. III, cap. III, \& VII, Madrid 1859, pp. 169-176 (v, item Ibid., pp. 142-145).

Medievalia Hispanica

Hispania Sacra 50 (1998) 
decirse similares. En lo que hace al caso tarraconense, se trata de tres o más Iglesias que conforman entre ellas un compacto bloque geográfico, claramente basculado hacia lo que se revelará con posterioridad foco permanente de conflictos para el Estado visigodo; de tres o más Iglesias, por otro lado, que dejan de asistir como por sistema - si vale la expresión - por un lapso de tiempo relativamente largo (hasta el punto de que sus hermanas coprovinciales se reúnen entre tanto en cuatro ocasiones). En cambio, por lo que hace a los sínodos de Valencia de 549 y de Braga de 561, las menciones de asistentes a los mismos se producen en las actas de forma que no permiten saber a ciencia cierta cómo se distribuyen geográficamente las Iglesias ausentes, tratándose por otro lado, en ambos casos, de ausencias limitadas a un solo sínodo. Por todo ello, estimo que no está fuera de lugar el preguntarse por las razones que hacen que cierto número de Iglesias de la parte occidental de la Tarraconense falten como por sistema a los sínodos que la provincia celebra en la primera mitad del s. VI. Otra cosa será atinar con las razones que en realidad determinan tales ausencias. En nuestro anterior tratamiento del tema hicimos exposición de nuestra hipótesis explicativa, y a ella nos remitimos como más plausible, mientras no se nos muestre otra mejor.

Llegados aquí, opina Larrea que nuestra propuesta explicativa se hace dificilmente aceptable. Y en demostración de lo dicho, extrae de nuestro trabajo, para criticarlas, unas pocas palabras, no muy felices quizá, pero que hallan su explicación dentro de un contexto. En nuestra exposición decíamos así: "En la primera mitad del s. VI y aun bien entrado el último tercio del mismo, el peso del aparato de poder visigodo en la zona no es todo lo fuerte y eficaz como para que pueda hacer operativa la institución provincial en los antiguos términos, e imponer consecuentemente (o facilitar en cualquier caso) a los obispos de la misma su asistencia a los sínodos de una iglesia provincial que debe de antojárseles extraña, en cuanto solidaria o sujeta a un poder político extraño". Reconocemos que lo de imponer pueda sonar raro, tratándose de reyes arrianos que tienen que vérselas con prelados católicos; si hemos de decir verdad, ni siquiera hacemos punto de honor del mantenimiento del término, el que apenas nos costaría retirar. Pero, aun así, pensamos que en lo sustancial tiene pleno sentido la frase en cuestión, en la medida en que sítúa el debate en sus justos términos. Hay un dato en las cartas del obispo Montano, insertas tras las actas del II Concilio Toledano del 527, que puede resultar significativo en este contexto, y es el de que la iniciativa de los católicos palentinos, de llamar a obispos alienae sortis para consagrar unas iglesias en Segovia, Buitrago y Coca, no fue para nada del agrado del rey, que veía en ello dañados sus intereses ${ }^{12}$. Si es

12 Conc. Tol. $I$, dos cartas del obispo Montanus, una a los hermanos y fieles del territorio Palentino, y otra al obispo Toribio, ed, de J. VIVES, part. pp. 49 y 51 s. Según les hace saber Montanus a los 
verdad lo que afirma E. A. THOMPSON ${ }^{13}$, que lo de alienae sortis debe ser entendido como de otra provincia eclesiástica (opinión que estimo mucho mejor fundada que la de G. Martínez Díez, que la interpreta como "de otra nación"14), habría que concluir que el arriano Amalarico se muestra dolido de que unos clérigos católicos - contra lo acostumbrado en la Iglesia - se propasen a llamar a obispos de otra jurisdicción eclesiástica para consagrar unas iglesias de pueblo: dolido, se nos precisa, porque en ello ve lesionados sus intereses (nec provinciae privilegium nec rerum Domini noscitur utilitatibus convenire...). $\mathrm{O}$ sea, que un rey arriano puede mostrarse dolido por actuaciones de unos curas de pueblo católicos, que no respetan la institución provincial, $\mathrm{y}$, sin embargo, se pretende que se despreocupe en absoluto de que los altos jerarcas de la Iglesia - los que de verdad detentan el poder en ésta- se atengan o no a los lazos de la communio y la subordinación jerárquica dentro de esa misma institución provincial... Y es que, en esas décadas de crisis e inseguridades del poderío visigodo en la Península, lo que parece estar en juego en la zona, a pesar de los esfuerzos desplegados al respecto por Teodorico el Amalo, es la pervivencia y operatividad del entramado político-administrativo heredado del Imperio (y, por ende, la operatividad del mismo instituto provincial en sus varios cometidos de orden fiscal, judicial y gubernativo, lo que explicaría la preocupación de Amalarico por un tema que se diría de exclusiva competencia eclesial), al tiempo que las élites dirigentes seculares y eclesiásticas de ámbito regional o local, conscientes de las virtualidades o promesas de esa situación de impasse, se dirían participar de forma más o menos abierta o soterrada en la lucha por el nuevo diseño de las áreas de poder. Y era en ese supuesto -es decir, en cuanto incapaz de asegurar el mantenimiento y operatividad de la vieja institucion provincial en sus antiguos cometidos y límitescomo tildábamos al aparato de poder visigodo de la primera mitad del s. VI de no ser todo lo fuerte y eficaz como "para imponer consecuentemente (o facilitar en cualquier caso)" a los obispos de la zona su asistencia a los sínodos de una iglesia provincial que debía de antojárseles solidaria de un poder político

Palentinos - sin sede propia de momento, por lo que parece [donec et consuetus vobis a Domino praeparatur antistes...] - la noticia de la irregularidad cometida había llegado a oídos del rey quien, como va dicho, no se sintí́ especialmente complacido por el hecho (nec provinciae privilegium nec rerum Domini noscitur utilitatibus convenire, quia iam ad ipsum huiuscemodi fama perlata est [...]). (p. 49). Más tajantes, Jas palabras en la carta a Toribio: si haec nostra amonitio in vobis nihil profecerit, necesse nobis erit Domini nostri exinde auribus intimare, pariter ef filio nostro Ergani suggerere. et huiusmodi ausum praecepta culminis eius vel districtio iudices non sine vestro detrimento severissime vindicabunt [...] (pp. 51s).

13 o. c., pp. 47s. "Evidentemente - escribe-m, el rey [Amalarico] consideró importante que los límites provinciales actuaran en cierto modo como rígidas barreras", incluso en lo eclesiástico.

14 Así, en la versión que preparó para la edición de los Concilios visigodos, de J. Vices de 1963 (pp. 49 y 51 ).

Medievalia Hispanica

Hispania Sacra 50 (1998) 
extraño. En tal situación de precariedad (e. d., de falta de operatividad y capacidad coercitiva) del viejo instituto provincial de ascendencia romana, y cuando por otro lado se está diseñando la nueva geografía del poder en la zona, no importaría tanto que los obispos de Tarazona o de Huesca "puedan ir hasta Zaragoza o Lérida" - según apunta Larrea-, o que el obispo Vicentius de Huesca se documente poseyendo, gestionando y recorriendo a menudo un patrimonio que se extiende de los valles pirenaicos hasta Zaragoza y Lérida (lo que, tal como suena, me resulta algo excesivo o no del todo probado) ${ }^{15}$. Lo que a la sazón estaría en juego, según lo dicho, sería la nueva geografía del poder, y en tal coyuntura no sería tan de extrañar que el episcopado - un episcopado convertido cada día más en pieza importante de las estrategias de poder, tanto de la monarquía, como de las grandes familias - se mostrara receloso o reacio a asistir a los sínodos de una provincia cuya perduración como tal puede ofrecerse menos prometedora políticamente para sus intereses o los del grupo familiar al que representa. Larrea pide "alguna prueba o indicio" en tal sentido. Si hubiera pruebas, el debate estaría concluido, y yo no presentaría esto como hipótesis explicativa. En cuanto a indicios, ${ }_{i}$ no lo es a su manera el que tres o más Iglesias de las que conforman el lado occidental de la Tarraconense dejen de asistir por un lapso de tiempo relativamente largo a los sínodos de su provincia? Para cerrar el apartado, y pues se habla de indicios, volveré a insistir en algo que señalaba en mi exposición anterior ${ }^{16}$ : ¿se ha reparado en que el episodio de Silvano de Calahorra define, seis o siete décadas antes, un escenario de enfrentamiento parecido al que definen ahora las Iglesias asistentes de la Tarraconense, por una parte, y las absentistas, por otra?

3. Larrea no parece de acuerdo con nuestra afirmación de que, aun en el supuesto de que se probase la presencia de una comunidad cristiana en la Pamplona bajoimperial, al no haber atestaciones de obispos en la ciudad con anterioridad a 589, cabría en principio retrasar la erección de una sede episcopal en

Is Excesivo, primero, porque el texto que sirve de base a esa afimación nada dice de que el obispo Vicente de Osca recorriese a menudo ese patrimonio; $\mathrm{y}$, segundo, porque las precisiones localistas que cabe deducir del texto no permiten asegurar que dicho patrimonio se extendiese "hasta Zaragoza y Lérida" [capitales, preciso yo], sino, en todo caso, a las terras de Zaragoza y Lérida (v. F. FITA: Patrologia visigótica. Elpidio, Pompeyano, Vicente y Gabino, obispos de Huesca en el siglo VI, en el "BRAH" 49, 1906, 137-169, concr. pp. 151-166, en que transcribe y comenta los documentos de donación del dícono y más tarde obispo Vicente al monasterio de Asán y a la Iglesia de Osca, respectivamente). Una última observación: el episcopado oscense de Vicente, y aun la fecha de su donación al monasterio de Asán - cuando era aún simple diácono (an̄o segundo del reinado de Agila [i551?]) - , se enmarcan claramente con posterioridad a la fecha de celebración del áltimo de los sínodos provinciales aquí considerados (el de Lérida, de 546), cuando muy probablemente se hallaba en vigor la prohibición de celebrar sínodos provinciales, atribuida por lo común al rey citado (cfr. $\mathrm{E}$. A. Thompson: Los Godos..., p. 49).

16 V. mi exposición anterior, n. 37 
Pamplona hasta que ésta pasa a manos visigodas ${ }^{17}$. Le parece que, para que esa hipótesis pudiera aceptarse, deberían admitirse "previamente y de manera encadenada" toda una serie de supuestos. No vamos a entrar a discutir lo que afirma sobre la necesidad de admitir previa y encadenadamente éstos, para que se verifique aquélla; pero, en todo caso, diremos algo sobre lo que entendemos de cada supuesto. Por lo que hace al punto a), nos parece que la Iglesia de Pamplona es tan capaz o "incapaz de dotarse de un obispo" como pueda serlo en su entorno más o menos inmediato Jaca, Tricio o Briviesca. Hay ciudades que documentan en fecha más o menos temprana comunidades cristianas en su seno, y que más tarde llegan a acreditarse como sedes episcopales; hay otras cuyos orígenes cristianos - presumiblemente, por azares de documentación-se asocian sin solución de continuidad con los comienzos de su acreditación como sedes episcopales; las hay también que, no obstante estar aureoladas de notable prestigio profano (no inferior, en cualquier caso, al de la Pamplona romana: piénsese en Clunia, capital de un conventus en el Alto Imperio, o en Virovesca, situada en uno de los puntos más neurálgicos de las vías de comunicación del norte hispano por entonces), nunca llegan a ostentar rango episcopal, aun cuando, como en el caso de la última citada, cuenten desde hora bastante temprana con comunidades cristianas en su seno; las hay, en fin, que, ignoradas prácticamente por la Antigüedad clásica, y sin que nada ostenten en su pasado que valga a realzar su brillo en el plano civil o eclesiástico -tal Auca ${ }^{18}$-, se acreditan andando el tiempo como sedes episcopales: jvariedad de fortunas, que con harta frecuencia viene determinada en mayor o menor grado por lo que Larrea llama "actuación de una autoridad exterior" (exterior,

17 Que conste que en nuestra exposición hablamos en términos de hipótesis, y no nos negamos en redondo a que con anterioridad pudiese haber sede episcopal en Pamplona. V. en este sentido lo que decíamos en la nota 77 .

18 En un trabajo de hace unos años expresábamos nuestra opinión sobre que la fundación de $A u$ ca como sede episcopal —caso de que hubiera que ver a ésta, según quieren los autores (cfr. L. SERRANO: El obispado de Burgos y Castilla primitiva desde el siglo V al XIII, 3 th. Madrid 19351936, concr. t. I, p. 16; D. MANSILLA: s. v. Burgos, en DHEE 1, 1972, 290; etc.), en la actual Villafranca de los Montes de Oca- parece traducir mejor, por su localizacion en las inmediaciones de la divisoria de aguas Ebro-Duero y en un contexto básicamente silvo-pastoril, los esquemas de ordenación territorial godos (v. A. M. JIMÉNEZ GARNICA: Los primeros establecimientos permanentes de Visigodos en Hispania, en "Hispania" 42, 1982, 485-503, partic. 490-502), que no los de la Iglesia paleocristiana, que, según se sabe, privilegia, ceteris paribus, el medio urbano y la vecindad de las grandes rutas de comunicación. Quiero decir, que en tiempos paleocristianos -y más, cuando éstos se llevan al s. IV y aun más allá, como lo hace alguno (v. L. SERRANo: $o$. c., t. I, pp. 19s) - se hace dificil de entender que se prefiera la creación de una sede episcopal en Auca a hacerio, por ej., en la cercana Virovesca, mucho mejor comunicada y de mayor prestigio urbano, sin duda (v. K. LARRAÑAGA ELORZA: En torno al caso del obispo Silvano de Calagurris: consideraciones sobre el estado de la Iglesia del alto y medio Ebro a fines del Imperio, en "Veleia" 6, 1989, 171-191, aquí p. 176 nota 20 ).

Medievalia Hispanica

Hispania Sacra 50 (1998) 
no sólo a la iglesia cristiana local -lo que, en medio de todo, resulta comprensible, habida cuenta de que la fundación de una nueva sede episcopal es asunto que no incumbe exclusivamente a ella-, sino también a la misma Iglesia provincial, que en no pocas ocasiones ha de transigir con los poderes seculares)! ¿Lo que en concreto sucede en Pamplona? En mi anterior exposición sobre el tema me hacía eco de las diversas respuestas que, más o menos plausiblemente, cabe dar a esa pregunta, entre las que, por supuesto, no se excluye la que afirma la presencia de obispo en la ciudad con anterioridad a la acción de fuerza de Leovigildo de 581. Lo que digo es que no me parecen tan determinantes las razones que se argumentan para negar toda verosimilitud a la que retrasa la fundación de sede episcopal en Pamplona a unos años después.

En el b), arguye Larrea que nadie puede asegurar, fundadamente, que la acción militar de Leovigildo de 581 afectase a Pamplona, porque no se sabe "en qué parte de Vasconia" se desarrolló esa intervención. Pero aún va más lejos, y se pregunta si "hay algún indicio, que no ya prueba, de que Pamplona haya estado fuera del control visigodo antes de 589" ( $\mathrm{sic})^{19}$. En cuanto a lo primero, podría contestar con lo de los escolásticos: accepta praemissa, nego consequentiam. Y es que del hecho de que no se sepa en qué parte de Vasconia tuvo lugar la acción de Leovigildo, y aun dando por probado que ésta no llegase a castigar a Pamplona (militarmente, quiero decir, lo que puede resultar defendible), no se sigue que no la afectase de otro modo, determinando algún tipo de cambio -es un decir-en la política de los poderes locales que controlaban la ciudad y su entomo más o menos inmediato. A lo segundo, respondería con otra pregunta: el paso del general de Eurico, Gauterit, por Pamplona en el $472^{20}$ ipuede de verdad ser estimado como punto de arranque de una presencia goda ininterrumpida en la ciudad, haciendo tabula rasa de cuanto adviene con posterioridad al desastre de Vouillé, no ya en el área circumpirenaica, sino a nivel de la Península? Y es que, por lo demás, ningún texto hay que explícitamente afirme que los Godos se apoderasen de Pamplona. Pero, si se da por bueno que ésta no estuvo fuera del control visigodo antes del 581, ¿a qué parte de Vasconia pudo atacar y someter Leovigildo? ¿Al valle del Baztán, tal vez? $\mathrm{O}_{i \mathrm{a}}$ áreas marginales que se escapaban del control de los funcionarios godos establecidos en Pamplona?

Por lo que hace al c), diremos que Leovigildo - sobre todo el Leovigildo que hubo de pelear contra el hijo alzado en rebeldía-- podía, si se quiere, ser

19 o. c., p. 321. Me imagino que hay aquí un baile de números, y que lo que quiso poner tal vez Larrea fue 581 - fecha de la citada intervencion militar contra Vasconia-- y no 589 -fecha de celebración del III concilio toledano-. Si no es así, tampoco tiene excesiva importancia el tomar una fecha u otra.

20 Chron. Gall, a. DXI, XVI. 
"muy capaz de instalar un obispo arriano" allí donde gustase. Sólo que los textos de época revelan que, llegado el caso, el monarca visigodo lo mismo podía imponer obispos arrianos (como lo hizo, según se sabe, en la Galicia sueva, aunque sin destituir a los católicos, que siguieron detentando sus sedes $^{21}$ ), como sustituir a uno católico caído en desgracia por otro de la misma fe nicena (caso del obispo de Mérida, Massona, que, al ser exiliado en el 582, fue sustituido por el católico Nepopis ${ }^{22}$ ). Lo que viene a decir que en el supuesto más o menos probable de que Leovigildo, con posterioridad a su acción militar de 581, hubiera intervenido en los destinos de la Iglesia cristiana de Pamplona (bien porque se apoderó de la ciudad, bien porque, como consecuencia de la nueva relación de fuerzas resultante en el área, indujo un giro llamémoslo filogótico en la política de los poderes locales que controlaban la misma), tal intervención no tendría por qué haber derivado - tratándose de un dirigente que, pese a su fe arriana, acertó a mostrarse por lo común sagaz y ecuánime en sus relaciones con los súbditos católicos ${ }^{23}$ - en la imposición de un obispo de su secta a una comunidad ciudadana que, sin excesivos riesgos de error, cabría estimar de fe nicena sociológicamente. A partir de ahí, se pueden plantear diversas hipótesis, con más o menos base de razones ${ }^{24}$.

Tras lo anotado, pienso que puedo excusarme de decir nada en punto al supuesto d), sobre el que, por otra parte, algo adelantamos en nuestra anterior exposición ${ }^{25}$. En cuanto a que el intervencionismo de los poderes políticos en la vida de las Iglesias pudiera llegar hasta a forzar, por los modos de persua* ción que juzgaran pertinentes ${ }^{26}$, la erección de una sede episcopal nueva (una de las hipótesis posibles, repito, no la única), arguyo a partir de lo que conocemos son prácticas más o menos usuales de la monarquía goda en su relación

${ }^{21}$ Cfr. E. A. Thompson: Los Godos..., pp. 104-108. Se habría tratado de dos organizaciones eclesiásticas paralelas

22 Vitas Patrum Emeritensium, V, VI, 135-138 (ed. A. MAYA SÁNCHEZ, Turnholt 1992, pp. 70s); v. también V, VIII, 43-54 (ed. cit., p. 76). V. al respecto J. I. Alonso CAMPOS: Sunna, Masona y Nepopis. Las luchas religiosas durante la dinastía de Leovigildo, en Los visigodos. Historia y civilización (Antigüedad y Cristianismo: 3, serie dirig. por A. GONZÁLEZ BLANCO), Murcia 1986, pp. 151-57.

${ }^{23}$ Cfr. E. A. THOMPSON: o. c.,pp. 94-104.

24 V. en nuestra anterior exposición la nota 77.

2s V.p. 300.

26 Entre los modos de persuasión no hay por qué excluir el acuerdo con los dirigentes eclesíasti$\cos$ de fe nicena leales al régimen, sobre todo si la fundación de la nueva dí́cesis se proyecta sobre distritos de frontera o de dominio incierto, cuyo desgaje o desmembramiento se supone no comportar excesivo sacrificio a la que se estima sede o diøcesis madre. Fue quizá por ese lado por donde le nacieron contradictores a Wamba, al forzar la creación de sedes nuevas en áreas ya de antes suficientemente cubiertas en lo eclesiástico (v. canon IV del concilio XII de Toledo de 68I, muy explícito, por otro lado, en punto a la violentia principalis bajo cuya insoportable presión se habría plegado el obispo de Mérida a ordenar un obispo para la villula de Chaves).

Medievalia Hispanica

Hispania Sacra 50 (1998) 
con las Iglesias. Llegado el caso, los reyes godos pueden -como Eurico o Leovigildo - desterrar a los obispos que les resultan molestos; pueden - tal Agila y los que inmediatamente le suceden - prohibir la celebración de sínodos provinciales de las Iglesias de fe nicena; pueden - tal Leovigildo- forzar la fundación o reposición de Iglesias episcopales de fe arriana; pueden - como Wamba, pero sin que resulte difícil hallar precedentes en la práctica de los reyes merovingios con los que hubo de tratar justamente Leovigildo ${ }^{27}$ - fundarlas de fe nicena, cuando así les interesa, etc., etc.

4. Cierto que la etapa que se extiende del 621 (año de la intervención de Suintila contra los Vascones) al 673 (año de la acción que protagoniza Wamba) es de penuria de fuentes de índole cronística propiamente dicha para el reino visigodo, penuria que afectaría - si se nos apura- a otras de interés histórico en general; pero no hasta el punto de que no quepa rastrear de algún modo a través de ellas lo que acaece a la sazón en el área. De algunas de ellas nos hicimos eco en nuestra anterior exposición ${ }^{28}$, y no hay razón para que volvamos ahora sobre ello. Diremos tan sólo que todos esos indicios (o como quiera deba llamárselos) cobran nueva dimensión herméutica hoy, a la luz de lo que vienen arrojando los hallazgos arqueológicos de Aldaieta, Buzaga, Fínaga, Alegría-Dulantzi, etc., a que aludíamos también en nuestra anterior exposición ${ }^{29}$. Por todo lo cual, estimo verosímil - y aun diría altamente probable- la hipótesis que interpreta el silencio de las fuentes godas sobre intervenciones militares en Vasconia entre 621 y 672 , no ya tanto como reflejo de una "penuria de fuentes cronísticas o historiográficas en general", según entiende mi estimado colega ${ }^{30}$, sino más bien como consecuencia de las dificultades por que

27 Tenemos el caso de Arisitum, constituido en obispado hacia el 570 por el rey de Austrasia, Sigeberto, quien lo confí al obispo Mondericus, sujeto de asendereada vida, mezclado de lleno en la convulsa política de aquellos años (v. GREGORIUS TURONENSIS: Hist. Fr., V, 5; L. DUCHESNE: Fastes épiscopaux de l'ancienne Gaule, t. I, 2. ed., Paris 1907, p. 316 nota 6, cuya interpretación de los hechos hemos seguido; v. en cualquier caso, L. BASCouL: s. v. Arisitum, en DHGE, IV, Paris 1930, cc. 180-182). Hay que señalar, en relación con lo dicho en la nota anterior, que Arisitum, dependiente de la civitas Nemausus (Nîmes), venía a ser como la capital de un distrito bastante extenso en la región montaffosa de las Cévennes, y comprenđía unas quince parroquias, que anteriormente habían sido de los Godos. Su constitución en obispado parece haber venido determinada por el hecho de hallarse en una zona de contacto entre Visigodos y Francos, rica en yacimientos de mineral de cobre y de plomo argentífero (v. M. RoUCHE: L'Aquitaine des Wisigoths alu Arabes (4I8-781). Naissance d'une région, Paris 1979, pp. 194s), y en la que menudearon los reajustes de fronteras en función de los vaivenes habidos en la suerte de anmas. Sobre el tema de la erección de nuevas sedes, v. más adelante en el apartado 5 .

28 V. el texto referido a las notas 91-101.

29 V.pp. 290 s.

30 Decimos esto aun pensando que no le falta pizca de razón a Larrea para hablar así. De hecho, que, aparte las registradas en las crónicas, pudieron haberse dado otras intervenciones militares, es cosa que se estima probable, y así lo darian a entender el epígrafe funerario de Oppila del 642 y 
atraviesa el aparato de poder visigodo, lastrado por sus propias contradicciones, para protagonizar (y rentabilizar propagandísticamente, cabría añadir) hechos de la entidad de los de Leovigildo, Suintila o posteriormente Wamba.

Pero demos por probado que en la etapa 621-672 se dan de hecho esas expediciones militares, y que sólo se debe a penuria de fuentes cronísticas y de otra índole el que de las mismas no haya quedado un suficiente contraste documental. Es que de esa guisa ¿sale quizá mejor librada la tesis que propugna el pleno control del aparato de poder visigodo sobre el área de Pamplona? Porque me pregunto: iexpediciones militares, contra quién, si se supone que Pamplona, por ej., se halla plenamente sujeta al dominio godo? Y ¿qué significa el hecho mismo de que las expediciones militares hayan de repetirse cada cierto tiempo?

Dicho lo cual, no me cuesta en absoluto desdecirme de las ofensas en que haya podido incurrir, por precipitado y poco reflexivo ${ }^{31}$, respecto de la persona del rey Chindasvinto. Aunque diré que lo de "política vacilante y medrosa" hacía referencia a la realeza goda de esa etapa en general, y que, por supuesto, no entraba en mis designios hacer derivar de la salud política del Estado la producción historiográfica de una época, sino significar de algún modo que épocas grises y de escaso contributo para el desarrollo y lanzamiento de ideasfuerza que actúan como aglutinadoras y dinamizadoras del cuerpo social, no suelen ser precisamente propicias para generar una actividad historiográfica del tipo de la isidoriana. Sin más.

5. Me daría por muy bien pagado si mi estimado colega diese por bueno lo grueso de mi argumentación en punto a que un décalage de unos 9610 años entre una operación militar de envergadura y la celebración consiguiente de un sínodo, no es razón para que al caso se hable de "relación muy vaga". La razón que argüía era bien simple, y se cifraba en que una acción militar de envergadura, tendente a sojuzgar y/o controlar administrativamente un país, no puede -si es que quiere de verdad obtener lo que persigue - limitarse a unas operaciones de castigo o a romper en el campo de batalla la resistencia del enemigo;

ciertas emisiones de monedas en las áreas de fronteras (cfr. A. BARBERO-M. VIGIL: Algunos aspectos de la feudalización del reino visigodo en relación con su organización financiera y militar [1970], en IID.: Sobre los orígenes sociales..., pp. 117s; E. A. THOMPSON subraya también la forma del todo incidental como llega hasta nosotros la noticia de ciertos acontecimientos de carácter bélico [Los Godos..., p. 184]). Pero ¿no estaría justificada en tales casos la sospecha de tratarse de acciones de poco brillo, o que redundarían incluso en demérito de las armas visigodas? En cuanto al epígrafe de Oppila, la literalidad del texto no parece obligue a pensar necesariamente en una gran expedición de castigo o algo por el estilo: Oppila es destinado con un convoy de armas a la frontera de los Vascones. Ahora bien, el convoy de armas podía muy bien tener como objeto abastecer de material algún enclave estratégico, y no destinarse inmediatamente para una ofensiva militar.

31 J. J. LARRBA: De nuevo en torno..., p. 322.

Medievalia Hispanica

Hispania Sacra 50 (1998) 
y en ese contexto hablaba de otras medidas de tipo estratégico-táctico (reforzamiento del dispositivo de defensa, puesta en marcha del aparato fiscal y administrativo, adoctrinamiento ideológico mediante erección de nuevas sedes episcopales, etc.) que asegurasen en el tiempo la perdurabilidad del éxito militar inicial. Ahora bien, visto lo que escribe en el apartado 5, habré de pensar que Larrea acepta en lo sustancial mi argumentación, pues sólo se ocupa de responder a lo que atañe al tema de la fundación de nuevos obispados. "¿Cuándo -inquiere" 32 - el ejército visigodo (o el ostrogodo, o el suevo, o el merovingio) ha tomado una ciudad y se ha empeñado en el adoctrinamiento ideológico erigiendo una nueva sede episcopal?" Al ser formulada así la pregunta, ¿puedo pensar que admite, cuando menos, el que la administración visigoda haya podido echar mano del adoctrinamiento ideológico - vía fundaciones monásticas o mediante el impulso dado a la vida eremítica, por ej.--, para asegurarse mejor el control de espacios no bien integrados en el reino? Siendo eso así, la dificultad estribaría en que se probase que echan mano también de fundaciones de sedes episcopales al mismo objeto. ¿Lo hacen?

Que, llegado el caso, los reyes godos tienen bastante pocos escrúpulos para interferir en la vida de las Iglesias y utilizar a éstas como instrumentos al servicio del propio poder, es algo que está más que probado, y sobre ello nos hemos pronunciado con claridad hacia el final del apartado tercero $0^{33}$. Como se sabe, se trata de una forma de entender y conducir las relaciones IglesiaEstado, que los historiadores eclesiásticos califican como césaropapismo: forma peculiar que, cualesquiera que sean las raíces de que se nutre, cuenta ya a estas alturas con una cierta tradición en estas partes del Occidente, que sabe ya de Iglesias nacionales que reúnen sínodos igualmente nacionales, convocados y presididos por el príncipe o su representante. ¿Se hallaría, pues, el límite de las prácticas césaropapistas de los gobernantes justo en lo que concierne a la fundación de una sede episcopal? Pudiendo un rey visigodo o franco valerse del formidable instrumento de poder que pueda eventualmente significarle la fundación de un nuevo obispado, ¿habrá que pensar que renuncia a ello por escrúpulo religioso o cosas por el estilo? No digo yo que sea fácil (en horas tan avanzadas del proceso de penetración cristiana, y cuando para estas partes del Occidente puede decirse cerrado en lo esencial el de constitución de nuevas sedes que vengan a cubrir jerárquicamente supuestos nuevos territorios de expansión) documentar casos en que los monarcas fuercen, mediante los recursos de convicción pertinentes, la fundación de nuevas sedes. Pero sospecho

32 Ibid., p. 322.

33 V. al respecto to que escribe E. A. THOMPSON: o. c., pp. 320s; C. SÁNCHEZ ALBORNOZ: Orfgenes de la nación espaflola. Estudios criticos sobre la historia del reino de Asturias, 3 tt., Oviedo 1972-1975, I, pp. 165-168. 
que al caso la dificultad estriba, no en lo inusual o arbitrario del procedimiento (dentro de lo que son modos y maneras de la praxis césaropapista), sino en que a esas alturas del proceso de asentamiento de la institución eclesial la red jerárquica puede estimarse prácticamente cubierta.

Con todo, hay casos en que los monarcas del tiempo aparecen fundando sedes episcopales. Arriba hicimos mención de la de Arisitum, fundada el 570, según anota Gregorio de Tours, por el rey de Austrasia, Sigeberto ${ }^{34}$. Nada dice aquél - celoso defensor de los derechos de la Iglesia, según se sabe- de que la nueva fundación encuentre contradictores en los círculos eclesiásticos, y eso que la misma resulta posible sólo a condición de recortar el territorio de la Iglesia de Nîmes (dependiente en lo político del reino de Toledo, no debemos olvidarlo) y, en proporción mucho menor, por lo que se estima, el de la civitas de los Ruteni ${ }^{35}$. Que la nueva sede responda a los intereses del momento del monarca merovingio, lo sugiere el hecho de situarse en un enclave montañoso poco ha arrebatado a los Visigodos ${ }^{36}$, y que, por las razones que sea (las estratégicas pueden al caso venir dobladas por las de interés económico, al revelarse la zona rica en yacimientos de cobre y de plomo argentífero ${ }^{37}$ ), continúa siendo punto de contacto y fricciones entre éstos y los Merovingios. Ahora bien, el que la nueva fundación no halle, según parece, contradictores en los medios eclesiásticos de obediencia franca, hallaría plausible explicación en el enfeudamiento de éstos a los intereses de la realeza y patria francas, y, en lo que pueda afectar en concreto al obispo de Rodez, en el hecho de proyectarse sobre distritos fronterizos o de dominio inestable, cuya amputación no comporta excesivo sacrificio a la que se estima una de las sedes o diócesis madre. De hecho, cuando en el s. VIII y tras la anexión de la Septimania por el imperio franco se normaliza de alguna manera la situación, vemos que se extingue la diócesis de Arisitum, para refundirse la práctica totalidad de su territorio en la díccesis de Nîmes, de la que en su mayor parte había sido desgajada ${ }^{38}$.

\footnotetext{
34 V. supra nota 27.

35 Ello explicaría de algún modo lo que dice GREGORIO DE TOURS (Hist. Fr., V, 5), de que en sus días -y aprovechando tal vez alguna vacancia de la sede, según sospecha $L$. BASCOUL (s. v. Arisitum, en DHGE, IV, Paris 1930, c. 181) - la diócesis había pasado a la jurisdicción del obispo de Rodez, Dalmatius.

36 Hay quien ha sospechado que la fundación de la diocesis pudiera haberse debido a los Visigodos mismos, luego de que, derrotados por Teodeberto en el 533, lograron, sin embargo, mantenerse aún por cierto tiempo en ese enclave (cfr. L. BASCOUL: s. v. Arisitum, en DHGE, IV, Paris 1930, c. 181). En tal supuesto, ¿habría que imaginarla de confesión arriana?

37 V. referencias supra en la nota 27.

38 Para una etapa algo anterior, cabria aducir el testimonio de HIDACIO (Chron., 102), referido al año 433, sobre que en el convento Lucense, y contra la voluntad del titular de la sede, Agrestius, fueron ordenados obispos Pastor y Siagrius ("In conventu Lucensi contra voluntatem Agresti Lucensis episcopi Pastor et Syagrius cpiscopi ordinantur"). Según sugiere C. SÁNCHEZ ALBORNOZ (Fuentes
} 
Hicimos también mención de las fundaciones de sedes, protagonizadas por Wamba. Pero ya vimos en el apartado 3 que éstas, "rápidamente anuladas" 39 por el concilio Toledano del 681 , no parecen a Larrea de las que "puedan citarse como ejemplo de la política corriente del reino". ¿Ni siquiera - me atrevería a preguntar - como expresión de la vigencia plena de prácticas césaropapistas justo en un príncipe que ciertos textos coetáneos de origen eclesiástico empiezan a titular sintomáticamente como religiosus o ungido del Señor ${ }^{40}$ ? Más arriba ${ }^{4 l}$ dejamos dicho por qué, a nuestro modesto entender, tropiezan con contradicciones las iniciativas de Wamba, y no es cosa de que volvamos aquí sobre lo mismo. Pero me permitiría, de todos modos, preguntar por qué se toleran otras fundaciones - las de Palencia, Osma y Oca, en concreto-, a datar, según se estima, en tiempos visigóticos ${ }^{42}$, y entre cuyos promotores $\longrightarrow 0$ supervisores, cuando menos- se hace difícil no imaginar la persona del príncipe, sabiendo lo que a esas alturas supone una sede episcopal en las estrate-

para el estudio de las divisiones eclesiásticas visigodas [1930], en ID.: Investigaciones y documentos sobre las instituciones hispanas, Santiago de Chile 1970, 66-107, concr. 104), ello parece debe interpretarse como que en un primer momento, para gobernar en lo espiritual a los gallaici del distrito lucense, había un solo obispo (y una sola diócesis), pero que luego, por imposición de alguien (¿la misma población civil urbana de trađición romana, quizá, o las oligarquias que la representaban, que a la sazón, y a despecho de la hegemonía sueva en la zona, mantenían aún algún tipo de control sobre los núcleos ubbanos de alguna importancia de la misma [v, al respecto R. D'ABADAL: Del reino de Tolosa al reino de Toledo, Madrid 1960, pp. 29s]?), hubo tres obispos (y tres distritos diocesanos). Pero hemos de observar que han sido muy otras las interpretaciones que del texto de Hidacio han venido dando otros autores (v., por ej., E. FloreZ: España Sagrada, IV, Madrid 1859, p. 103; A. GARCía CONDE - A. López VALCÁRCEL: Episcopologio lucense, Lugo 1961, pp. 13-23).

39 Pero ilo fueron todas? Del canon IV del sínodo Toledano XII no parece deducirse tal. Se acordó ciertamente que la nueva fundación de Chaves quedara "bajo la institución monástica, sin gozar de privilegio episcopal" (buscándose de paso una solución de compromiso para el obispo Cuniuldus, al constar "haber sido elevado, no por ambición, sino por mandato del rey"), y se decretó también que "en adelante" no se constituyeran obispos donde antes no los hubo; pero nada se dice de que fueran suprimidas otras sedes que fueron igualmente fundadas por Wamba (si nos atenemos a la letra del citado canon IV, Wamba no se limitó a las fundaciones de Chaves y de la iglesia castrense de los santos Pedro y Pablo en el arrabal de Toledo, sino que hizo lo mismo "in aliis vicis vel villulis"...).

40 CONC. TOLED. XI: ed. de J. VIVES, pp. 344s, 367; S. JUliÁN DE TOLEDO: Historia Wambae regis, passim, v. g., 7; 9; 1 ; etc. Al subrayar el carácter sacral del princeps, se habría querido signifjcar de igual modo la supeditación del mismo a una línea de actuación inspirada en la Biblia y sometida por ello a las directrices de la jerarquía eciesiástica (v. S. TELLLET, L'Historia Wambae, est-elle une oeuvre de circonstance?, en Los visigodos..., pp. 41424; Y. GARCíA LóPEZ: La cronología de la 'Historia Wambae', in "Anuario de Estudios Medievales" 23, 1993, 121-139).

41 V. supra en el apartado 3, sobre todo nota 26.

42 Palencia aún en el 527 aparece sin constituirse en obispado (v. CONC. TOL. II, carta del obispo Montanus a los hermanos e hijos del territorio Palentino; A. MOLINA: Las tierras de Palencia durante la monarquía goda, en J. GonZÁlez [coord.]: Historia de Palencia, I: Edades Antigua y Medieval, Madrid 1984, pp. 129-153, concr. 132), y Oca y Osma son de fundación posterior a mediados del s. VI (sobre Oca, v. lo que escribimos más arriba en la n. 18), 
gias del poder. Anotaremos, en fin, que no faltan autores que interpreten la aparición, a finales del s. VI, de las sedes Elotana ${ }^{43}$ y de Bigastro ${ }^{44}$ en el Levante -en zonas del interior, que se saben fronterizas entre Visigodos y Bizantinos - como resultado de las operaciones que por un lado y otro se llevan para la conquista y control del territorio, sea que se estime tratarse de sedes de fundación bizantina, o, por contra, de sedes erigidas por los Visigodos ${ }^{45}$, según van recuperando terreno. Lo de que las nuevas fundaciones obedezcan a razones de tipo coyuntural-estratégico, dictadas por los imperativos de la guerra, quedaría también sugerido por el hecho de que la sede Elotana se refunde en la de Elche, tan pronto es ésta conquistada ${ }^{46}$.

6. No todo lo que en el apartado $6 \mathrm{mi}$ apreciado colega me atribuye -con un respetuoso "si no he comprendido mal", debo reconocerlo- lo he dicho (o me parece haberlo dicho) tan rotundamente como suena en sus formulaciones. Así, la hipótesis que formula en el a), se formula por mi parte como una de las posibles, no la única ${ }^{47}$. En cuanto al c), me parece me hace decir un poco más de lo que en realidad dije, porque lo que en la n. 85 - a que remite- decía de hecho es que veía "encajar bastante bien con la figura de Wamba y con su programa de restablecimiento de las bases del Estado visigodo [...] una cierta delicada presión sobre el titular de la iglesia pamplonica, tendente a restablecer (o fortalecer) los vínculos [...] que lo ligaban al Estado visigodo". Sólo una nimia cuestión de matiz, pero matiz, al cabo. Y el que, tras la delicada presión del aparato de poder godo sobre el titular de Pamplona, éste deje de asistir al concilio XII de Toledo o asista mediante delegado al XIII, ¿qué puede tener de extraño, si toda la Narbonense y Tarraconense, sometidas en principio a la misma presión, se comportan de forma igual o casi igual?

Parece, en fin, achacarme Larrea "hacer equilibrios para salvar las dificultades" que implica la hipótesis a que me inclino. No se lo niego. Pero le pre-

43 Aparte de en la Constitutio Carthaginensium sacerdotum de 610, inserta tras las actas del XII Conc, toledano de 681 (el último de los firmantes del texto es Sanabilis, sanctae ecclesiae Elotanae episcopus), se documenta en el VII Concilio Toledano del 646, en que, sin embargo, Winibal se presenta ya como "sanctae ecclesiae Ilicitanae qui et Elotanae episcopus" (CONC. TOLET. VII, ed. de J. VIVES, p. 257). La sede ilicitana venía ya figurando en la persona de Serpentinus desde el Conc. IV de Toledo de 633 .

44 Se documenta por primera vez en el IV concilio Toledano de 633, aparte de en la citada Constisutio Carthaginensium sacerdotum de 610 (v. nota anterior).

45 En el caso de Bigastro parece seguro tratarse de fundación goda (v. la referencia del trabajo de $\mathrm{J}$. Vives, citado en la nota siguiente).

$46 \mathrm{Cfr}$, al respecto J. VIVES: Nuevas diocesis visigodas ante la invasión bizantina, en Spanische Forschungen 17, 1961, 3ss; L. A. GARCíA MORENO: Estudios sobre la organización administrativa del reino visigodo de Toledo, en "AHDE" 44, 1974, 5-155, concret. 90-92; A. GoNZÁLEZ BLANCO: El decreto de Gundemaro y la historia del siglo VII, en Los visigodos..., pp. 159-69, part. pp. 160s.

$47 \mathrm{~V}$., por ej., en mi anterior exposición la nota 85.

Medievalia Hispanica

Hispania Sacra 50 (1998) 
gunto a mi vez: es que ¿no es consustancial a la hipótesis el que se plantee sobre un más o menos difícil equilibrio - o encaje- de los datos de la experiencia con un supuesto interpretativo dado? $O$ es que $\measuredangle$ no ha de hacer también él equilibrios, para dar visos de credibilidad a la hipótesis explicativa que preconiza? En última instancia, la mayor o menor credibilidad de una hipótesis depende de que cuadre mejor o peor con los hechos de experiencia o comprobados, de los que como explicación última - a título conjetural, por supuesto- se postula, dejando de ser hipótesis, para convertirse simplemente en tesis, cuando no necesita de equilibrios y ayudas de ese tipo para sostenerse.

En cuanto a que, "desde la llegada de las tropas de Eurico hasta la batalla de Guadalete, no hay ni una sola prueba de que ni el núcleo urbano ni el conjunto de la civitas de Pamplona haya estado jamás en manos de nadie opuesto al reino visigodo", querría, ante todo, que mi estimado colega precisara cómo ha de interpretarse la noticia de la Chron. Caesaraugustana, referida al año 542, en que, hablando de la expedición de los "cinco reyes de los Francos", se dice que la misma pasó por Pamplona, antes de proseguir camino hacia el valle medio del Ebrot8; querría, igualmente, que precisara hasta dónde se extendia en la Antigüedad Tardía "el conjunto de la civitas de Pamplona". La verdad es que no sabemos a ciencia cierta qué territorio preciso - entre las otras po-leis vasconas más o menos próximas, que cabe citar como posibles candidatas a ser también cabezas de civitates (Calagurris, Graccurris, Cara, Segia, Andelos, Araceli, Tarraga, etc. $)^{49}$ - pueda corresponder a Pompaelo en el Alto Imperio,

48 Ad ann. 542: Hoc anno Francorum reges $V$ per Pampelonam Hispanias ingressi Caesaraugustam venerunt, qua obsessa per quadraginta novem dies omnem fere Tarraconensem provinciam depopulatione triverunt. (ed. TH. MOMMSEN en $M G H, A A, 1_{12}^{2}$, Berlin 1894, p. 223). Es sabido que no faltan autores que interpreten la referencia a Pamplona como sejal de que los Francos se hicieron con la ciudad antes de continuar camino hacia el valle medio del Ebro (v., asi, J. SAYAS ABENGOECHEA: De Historiae Vasconiae rebus cotroversis, en ID.: Los vascos en la Antigüedad, Madril 1994, 177-223, concr. 207 n. 72). Y, si se objeta que el texto, en su literalidad, nada dice de que Pamplona pasase a manos de los Francos, cabe responder asimismo que tampoco el tex to de la Chronica Gallica $a . D X I$ - el que da pie a hablar de la ocupación de Pamplona por Gauterit- dice en su estricta literalidad que éste se adueñase de la ciudad vascona, sino que, "a través de Pamplona, Zaragoza y las ciudades vecinas" (el mismo acusativo precedido de per en ambos textos), se hizo con las Hispanias (651). Es interesante ver cómo la referencia de la Chronica Gallica se desarrolla en ISIDORO: qui [Euricus] post captom Pampilonam Caesaraugustam invadif totamque Hispaniam superiorem obtinuit (o, en la versión más larga: inde [Euricus] Pampilonam et Caesaraugustam misso exercitu capit superioremque Spaniam in potestatem suam mittit) (Hist. goth., 34).

49 Cfr. Plinjo: Nat. hist., 3, 24; PTOLOMEO: Geogr., 2, 6, 66 (67), que nombra hasta quince poleis. V., empero, en este punto J. SAYAS ABENGOECHEA: Ad census accipiendos de ciudades vasconas y várdulas y la legatio censualis de un pamplonés, en ID,: Los vascos en la Antigüedad..., pp. 161176, o también M. J. PEREX AGORRETA: Los Vascones. El poblamiento en época romana, Madrid, 1986, para apreciar la poca claridad que por culpa de las insuficiencias de nuestras fuentes de información reina en todo este asunto del ordenamiento político-administrativo del territorio de los Vascones. 
cuando con el paso del tiempo va documentándose como civitas, respublica y aun como municipium. Menos acertamos a ver cuál pueda corresponderle en la fase tardoantigua, una vez que se disuelve el Imperio de Occidente. ¿ Pasa con nuestra civitas lo que con las civitates de la Novempopulania, por ej., en que el territorio de la civitas y el del obispado se recubren? Pero en ese caso ¿quién atiende espiritualmente en la fase tardoantigua a las viejas po-leis (y presuntas cabezas de civitates, conjeturo) de Andelos y Cara, que en ningún momento se documentan como sedes episcopales? $O$ ¿hay que pensar que ésas pierden en el ínterim su condición de po-leis (y cabezas de civitates), para refundirse como simples vici o aldeas en alguna de mayor renombre? $\mathbf{Y}$, si en el caso de Pamplona nos hallamos de verdad frente a una civitas ampliada -ampliada, tanto desde el punto de vista de la responsabilidad civil, como de la eclesiástica-, ¿en qué dirección y hasta dónde alcanzó tal ampliación? Estimamos que se trata de cuestiones o aspectos a elucidar, antes de proceder a afirmar -0 negar - lo que LARREA afirma en ese punto a), como algo que "convendría no olvidar"s0. Por el momento, lo que sé es que lo de la "civitas de Pamplona" me ha sonado un tanto lejano, referido a esos años y estos pagos ${ }^{51}$. No quiero con ello decir que la vieja civitas de tradición romana - como referencia ordenadora del espacio en lo político-administrativo- haya dejado de existir en el Estado visigodo, ni mucho menos, pues en éste, según se sabe, aun consumada la ruina y desaparición de las curiae municipales, la civitas viene a resultar un referente esencial, presidido y gobernado por comites $\mathrm{o}$ iudices y otras instancias de poder local ${ }^{52}$. Pero uno no puede menos de recordar lo que no hace mucho todavía, y referido a los tiempos visigóticos, escribía J. M. LACARRA sobre que "Pamplona había dejado de ser cabeza de un distrito [cabeza de $c i$ vitas, interpreto yo], para ser una supervivencia de un pasado en trance de extinguirse"s3. Mas, dejando ahora de lado esto y centrándome en las cuestiones que suscitan las afirmaciones de mi colega en la parte final de su apartado 6, me permitirá que le remita a lo que dejé escrito arriba, respondiendo al

so De nuevo..., p. 323.

\$1 Pamplona, sin embargo, figura como urbs en la rúbrica que acompaña a la Epistola Honorii. conservada en el códice de Roda (v. J. M. LACARRA: Textos navarros del Códice de Roda, en "EEMCA" 1, 1945, 193-283, concr. p. 268), o en la Chronica Gallica a. DXI, 651 ("Gauterit comes Gothorum Hispanias per Pampilonem, Caesaraugustan et vicinas urbes obtinuit"). Por supuesto que la urbs tenía o tuvo su territorium... Pero ¿hasta dónde se extendían sus límites?

52 Cfr. C. SÁNCHEZ AlBORNOZ: Ruina y extinción del municipio romano en España e instituciones que lo reemplazan, Buenos Aires 1943.; ID.: El gobierno de las ciudades en España del siglo $V$ al $X$., en La città nell'alto medioevo. $10-16$ aprile 1958 (= Settimane di studio del centro italiano di studi sull'alto Medioevo, VI), Spoleto 1959, 359-391; E. A. THOMPSON: Los Godos..., pp. 139-43, $151-53$ y 162-68; L. A. GARCíA MORENO: Estudios sobre la organizacion administrativa..., pp. 8-12, 53s.

53 Historia política del reino de Navarra desde sus orígenes hasta su incorporación a Castilla, Pamplona 1972, I, p. 27.

Medievalia Hispanica

Hispania Sacra 50 (1998) 
punto b) del apartado 3. Y es que - vuelvo a preguntar- el paso de Gauterit por Pamplona en el 472 ipuede, de verdad, ser estimado como punto de arranque de una presencia goda ininterrumpida en la ciudad, haciendo tabula rasa de cuanto ocurre con posterioridad al desastre de Vouillé? Y, si hay que dar por bueno que entre el 472 y 711 "ni el núcleo urbano ni el conjunto de la civitas de Pamplona" estuvo nunca "en manos de nadie opuesto al reino visigodo", ¿contra quién dirigieron sus expediciones los Leovigildo, Recaredo y demás? ¿Contra quién erigí Leovigildo su Victoriacum, y Suintila su Ologitim u Ologicus, ubicado tradicionalmente en el Olite actual? Y ¿qué hay de los hallazgos de Aldayeta, Buzaga, el llamado cementerio visigodo de Pamplona (!), Fínaga, Alegría-Dulantzi y, últimamente, núcleo viejo de Gasteiz? Aspecto, éste de los hallazgos, al que se diría alérgico mi estimado colega, porque en ningún momento de su doble aportación lo aborda ${ }^{54}$, a pesar de que en mi artículo precedente hacía expresa e inequívoca referencia al mismo. Pienso, con todo, que éste - y otros que señalaba también en mi trabajo, y han quedado igualmente obviados o sin una suficiente contestación en el suyo ${ }^{55}$ - son aspectos que tarde o temprano habrá de tratar de integrar Larrea en su teoría explicativa, no obstante que para ello haya de hacer equilibrios -lo mismo que veía hacíamos nosotros - en la cuerda más o menos floja de una hipótesis.

7. Dejando de lado - por menos relevante- lo de que en la lectura de la Historia Wambae le atribuyo una originalidad que no le corresponde ${ }^{56}$, me ceñiré al tema de la participación de Lupo y los Vascones en la conjura del $d u x$ Paulo contra Wamba. Los datos - sintetizados a nuestro objeto- son éstos: 1) que el dux Paulo, decidido a liderar el movimiento sedicioso contra Wamba, prolatis promissisque muneribus, se procura el apoyo de nutridos contingentes de Francos y Vascones; 2) que, antes de dirigirse a la Septimania contra el rebelde, el monarca godo reduce a los Vascones en la península, quienes han de entregar rehenes y pagar los tributos (los que les exige -interpreto- la administración goda y aquéllos se resisten a entregar); 3) que una vez en la Septimania, y aplastado el movimiento sedicioso, Wamba pone en fuga al dux Lupo, que acude tarde en apoyo de los rebeldes.

Planteadas así las cosas, es más que evidente que en la literalidad del texto de S. Julián nada hay que permita afirmar la participación conjunta de vascones de ambos lados de los Pirineos en los hechos de que se trata. Lo que no

\footnotetext{
54 No entiendo como abordar la huidiza y nada comprometida referencia al tema que hace Larrea en la parte final del artículo (v. El obispado de Pamplona..., p. 145).

ss $\mathrm{V}$., por ej., lo que señalábamos en la nota 129 de nuestro trabajo anterior. A tener en cuenta en ese contecto el art. de $\mathrm{E}$. LÓPEZ MELERO cit. en la nota 58.

56 En realidad, to único que digo en mi artículo es que Larrea "se aparta de las lecturas al uso en puntos importantes" (pp. 310 y 312); no, que sea el único o el primero en hacerlo.
} 
obsta a que podamos sostener la verosimilitud de tal hipótesis sobre la base de las siguientes consideraciones. No cabe determinar, por supuesto ${ }^{57}$, la procedencia trans- o cispirenaica de los Vascones que, prolatis promissisque muneribus, se procura Paulo en los preámbulos del drama ${ }^{58}$. Podemos con todo pensar, con cierta plausibilidad, que, entre los contingentes de tropa de que se hace acompañar Lupo en su fracasado intento de apoyo a los partidarios de Paulo, se den esos Vascones que sabemos constituyen a la sazón la punta de lanza de los duques aquitanos en sus esfuerzos de dominación en el área aquitana y en el Midi ${ }^{59}$. Siendo eso así, y teniendo en cuenta, por otro lado, 1) que, referida a las tropas que apoyan al dux aquitano, así como a las gentes que combate Wamba en la península antes de su marcha a la Septimania, la Historia de S. Julián no habla sino de Vascones - sin distinguir entre cis- y transpirenaicos-; y, 2) que los recientes hallazgos arqueológicos (los de Aldayeta, Buzaga, Fínaga, Dulantzi-Alegría, etc.) están revelando un insospechado mundo de relaciones entre gentes que viven a la sazón a uno y otro lado de la cadena pirenaica (poniendo al descubierto episodios de asentamiento estable de comunidades humanas con notable presencia de lo militar, y con ajuares que remiten indefectiblemente a un horizonte de cultura material de adscripción norpirenaica, calificado genéricamente como franco y en algunos casos de facies aquitana), siendo ello así - repito-, opino que no es excederse mucho plantear - a título de hipótesis, cuando menos, como lo hace A. Azkárate, o el mismo M. RoucHE ${ }^{60}$ - lo de la participación conjunta de Vascones de ambos lados de los Pirineos en la revuelta contra Wamba.

En fin, reconozco haber podido malinterpretar el pensamiento de mi apreciado colega, al entender referido a la Vasconia en general lo que, en su intención, venía dicho sólo respecto a la actitud de la aristocracia local de la civitas de Pamplona, actitud que cree "esencialmente la misma que la de las otras civitates de la Tarraconense en los decenios finales del reino de Toledo"6?

\footnotetext{
$\$ 7$ Pero sospecho que Larrea no se avenđrá con esta afirmación, inclinándose, más bien, por la procedencia transpirenaica de esos Vascones que intervienen mercenariamente en los prolegómenos del dranna (p. 324).

58 S. JULIÁN DE TOLEDO; Historia Wambae.., 8. Recientemente, R. LóPEZ MELERO se ha inclinado por pensar tratarse de Vascones cispirenaicos, "porque es dificil de creer - razona - que, siendo como eran [los Vascones] enemigos tradicionales de los Francos, hubieran participado con ellos en una misma alianza" (Una deditio de los Vascones, en I Congreso General de Historia de Navarra, en "Príncipe de Viana" 48, 1987, Anejo 7, pp. 465-85, concr. 466s nota 4). Pero hemos de reconocer que tal forma de argumentar pierde fuerza cuando tras los Franci citados por S. Julian se ven, como lo hace M. ROUCHE (L'Aquitaine...,,p. 102), no a los Francos-Francos, sino a los Aquitanos - supuestos vasallos del rey franco-m que comanda Lupo.

59 Cfr. M. RouCHE: L'A quitaine des Wisigoths aux Arabe..., pp. 87-132.

60 O. c., p. 102.

61 J. J. LARREA: De nuevo..., p. 323.
}

Medievalia Hispanica

Hispania Sacra 50 (1998) 
Ciertamente, "va un trecho" --según se expresa- - de una cosa a la otra y, en ese sentido, no puedo sino presentarle mis excusas. Pero, en cualquier caso, desearía hiciese ver de forma precisa e inteligible en qué medida la actitud de la aristocracia local de la civitas de Pamplona se distingue (si es que se distingue...) de la actitud de otras civitates vasconas del área peninsular (si es que existen, y resultan operativas aún por ese tiempo) y, en general, de la de esa Vasconia 'global' que uno supone (ingenuo suponer, me temo) liderada justamente por esa misma aristocracia local.

8. Veo que mi estimado colega centra su apartado 8 en un tema de sintaxis latina, terreno en el que - he de reconocerlo- no me siento muy a mis anchas. Pero he sometido el texto isidoriano debatido al análisis de otros colegas más impuestos en el idioma de Cicerón, y su interpretación no difiere en lo esencial de la mía. Incursus -que yo sepa, y así lo anotan los diccionarioslleva incluida la preposición de acusativo in, y el verbo incurrere, de donde deriva, intransitivo en general, pide en construcción el acusativo precedido de in, siendo su sentido más normal y ordinario el de invadir, incursionar, hacer una salida contra, y otros como el de arrojarse contra, hacer irrupción en, atacar, etc. Resulta que el término infestare - presente asimismo en el pasaje isidoriano en discusión- lleva también aparejada la preposición de acusativo in con sentido de contra, referida aquélla, según anota mi apreciado colega, a la provincia Tarraconense. Pero no es eso sólo. En los otros dos casos en que el Hispalense se refiere a los hechos de armas que median entre Godos y Vascones, a éstos se describe protagonizando "inruptiones" en los días de Recaredo $^{62}$ (otro término que lleva inclusa la preposición in, y ha de traducirse como irrupción o invasión...), o sufriendo acciones destructivas y de estragos por parte de Gundemaro ${ }^{63}$ (justamente, el trato que un ejército reserva a un territorio que se estima enemigo y extraño). Dicho lo cual, y habida cuenta también de que la acción de Leovigildo es vista por JUAN DE BICLARO como ocupación parcial de Vasconia ${ }^{64}$, y de que el mismo Isidoro presenta los hechos subsiguientes a la acción de Suintila como deditio o rendición de unos Vascones que antes por lo visto se le resistían ${ }^{65}$, creo plenamente justificada en el texto isidoriano la interpretación de los hechos que proponía: tan justificada, al me-

\footnotetext{
52 Hist. Goth., 54.

63 Ibid., 59 ("una expeditione uastauit"). Vastare - asolar, artuinar, despoblar.

64 Chron. [ad ann, 581?]: "Leovegildus rex partem Vasconiae occupat et civitatem, quae Victoriacum nuncupatur, condidit". Es sabido que Isidoro nada dice expresamente de la expedición leovigildiana contra Vasconia.

65 Hist. Goth., 63: "[...] confestim quasi debita iura noscentes remissis telis et expeditis ad precem manibus supplices ei colla submitterent, obsides darent, Ologicus ciuitatem Gothorum stipendiis suis et laboribus conderent, pollicentes eius regno dicionique parere et quicquid imperaretur efficere". Cfr. R. López MELERo: Una deditio de los Vascones..
} 
nos, como la de él, teniendo en cuenta, sobre todo, lo que revelan los yacimientos arqueológicos de Aldaieta, Buzaga, Fínaga, etc., a que nos hemos referido en otras ocasiones ${ }^{65}$.

Un último apunte, relativo éste a la primera aportación de Larrea en la revista. ¿Está tan seguro de que fuese imposible en los días de Wamba in Tarraconensem provinciam accedere, partiendo de Cantabria ${ }^{67}$ ? Formulo la pregunta, porque no son pocos los estudiosos, como es notorio, que dan como altamente probable el que el ducado de (la provincia de) Cantabria sea una realidad para los días de Wamba ${ }^{68}$, si no ya con anterioridad ${ }^{69}$. Y es que una cosa es la realidad provincial de los días altoimperiales, otra la del Bajo Imperio, otra la de los días de Leovigildo, y otra, en fin, la de los días de Wamba; una, la idea que puedan hacerse los dirigentes godos o hispanogodos sobre los límites que, en razón de su antigua configuración, deban corresponder a la provincia Tarraconense (y su pretensión - más o menos legítima- de restablecerla en esos primitivos términos), y otra la realidad que por imperativos diversos se impone, y hace que la provincia Tarraconense visigoda sea mucho más reducida aun que la romana bajoimperial por obra de la constitución de un nuevo distrito provincial en Cantabria y también por la persistencia de un espacio irreductible en los Pirineos occidentales. $O$ ¿no había tal espacio irreductible?

9. Son dos las cuestiones que plantea mi estimado colega en el apartado 9 , cuestiones que pienso haber tratado suficientemente en lo expuesto hasta aquí. a) En lo que hace a que los Vascones de la Historia Wambae aparecen como agentes exteriores al reino godo, expuse mi punto de vista en mi anterior artículo y, sobre todo, en la n. 129 de la misma (que, por cierto, no ha hallado por su parte la respuesta que habría esperado) ${ }^{70}$. b) En cuanto al tema de la supuesta participación conjunta de Vascones de uno y otro lado de la cadena pirenaica en el complot contra Wamba, he dicho ya lo que pienso en el apartado 7 , y no es cosa de que vuelva aquí sobre lo mismo. Aprovecharé, empero, la

66 ¿Resulta tan dificil de aceptar lo de que "en el horizonte mental del hispalense la Vasconia de los Vascones problemáticos [...] había dejado de asociarse con la Tarraconense clásica"? Palabras que inclúa yo en la nota 119 , y critica en este apartado mi apreciado colega.

67 Así se expresa en El obispado de Pamplona..., p. 140.

68 Cfr. L, A. GARCía MORENO: Estudios sobre la organización administrativa..., pp. 138-147; J. ORLANDIS: Historia de España. La España visigótica, Madrid 1977, pp. 216.

69 J. GoNZÁlez ECHEgARAY: Los Cántabros, Madrid 1966, p. 233; A. BARBERo - M. ViGil: Sobre los orígenes sociales de la Reconquista: Cántabros y Vascones desde fines del Imperio Romano hasta la invasión musulmana, en IIDEM: Sobre los origenes sociales de la Reconquista, Barcelona 1974, pp. 87s; el mismo A. BESGA MARROQuíN.: La situación política de los pueblos del Norte de España en la época visigoda, Bilbao 1983, p. 84.

30 Remitiría al autor al art. ya cit. de R. LÓPEZ MELERo (p. 473 nota 19), en que la rendición de los Vascones, tras la acción de castigo protagonizada por Wamba (S. IULIANUS: Hist. Wambae, 10), es interpretada explícitamente como un caso de deditio.

Medievalia Hispanica

Hispania Sacra 50 (1998) 
ocasión para añadir que los más que probables apriorismos de un lado -al suponer actuando de forma unitaria en lo político una realidad de pura base étnica, presente, sin embargo, de forma inequívoca a un lado y otro de la cadena pirenaica - se contrapesan a menudo con apriorismos de otro signo, que sobredimensionan la operatividad de unas divisiones administrativas (las de Hispania y las Galias, por ej., en función del eje pirenaico), eficaces, sin duda, en mayor o menor grado, cuando los determinismos geomorfológicos se doblan con los que induce un aparato de poder fuerte, pero que pueden no serlo tanto - sobre todo, frente a comunidades en cuyo hacer económico lo pastorilganadero juega al parecer un papel importante- cuando las estructuras de poder se revelan más endebles. Y es que ¿son tan decisivos los Pirineos como línea de demarcación en la Antigüedad Tardía? Pero ¿qué Pirineos? ¿los que OROSIO $^{71}$ y otros autores antiguos ${ }^{72}$ ven prolongándose a todo lo largo de la cordillera cantábrica?

10. Son varios los puntos que toca Larrea en su apartado 10 , y de enjundia algunos, que precisarían de un tratamiento más desahogado que el que pueda yo dedicarles en estas notas apresuradas y de circunstancias. Pero, toda vez que estamos en ello, trataré de responder por lo menos a lo más esencial de sus apreciaciones.

Totalmente de acuerdo con él en cuanto a que a estas alturas del debate el punto crucial del mismo ha derivado a la manera de entender los procesos globales de la Vasconia tardoantigua. Pero eso estaba de alguna forma cantado, por lo mismo que el desarrollo de la Iglesia institucional y sus relaciones con los poderes de este mundo son parte inseparable de tales procesos. Sobre éstos y la interpretación del período en general, J. J. Larrea promete para dentro de poco una obra de mayor porte, que será, por supuesto, bienvenida -no le quepa la menor duda - a esta parcela de la historiografia, tan trabajada de apriorismos de todo tipo, como necesitada de mentes lúcidas y sagaces como la suya. La obra a venir aportará sin duda luces nuevas para tratar del tema que nos ocupa, y es lógico esperemos a poder contar con ella, antes de formar un juicio definitivo sobre lo que al respecto piensa nuestro colega. Pero, toda vez que en su tratamiento del tema concreto de la sede episcopal de Pamplona y en la nota en que replica a nuestra comunicación anterior no han dejado de desli-

$7 \mathrm{VI}, 21,2$.

72 V. recogidas algunas referencias curiosas en J. GIL: Para la edición de los textos visigodos y mozárabes, en "Habis" 4, 1973, 189-234, concr. 230-233; v, item K. LARRAN̈AGA ELORZA: El pasaje del Pseudo-Fredegario sobre el dux Francio de Cantabria y otros indicios de naturaleza textual y onomástica sobre presencia franca tardoantigua al sur de los Pirineos, en "Archivo Español de Arqueología" 66, 1993, 177-206, concr. 205s "Epílogo sobre las funciones y la percepción sacial de la frontera en las sociedades antiguas"). 
zarse entretanto, como no podía menos de ser, ciertos rasgos definitorios de su propia manera de ver tales procesos y aun enjuiciamientos claramente críticos de la foma en que entienden otros los mismos, diremos algo aquí sobre lo que afecta a este último apartado.

Se lamenta Larrea de que en la historia vasca antigua se haya eludido "el ejercicio inexcusable de crítica de las fuentes". ¿No le parece algo fuerte, referido a textos como los de Prudencio, Paulino de Nola, Venancio Fortunato, Isidoro, etc., sobre los que han pasado una y mil vez los C. Sánchez Albornoz, J. M. Lacarra, J. Caro Baroja, A. Barbero y M. Vigil, J. M. Blázquez, J. Fontaine (especialista en historia literaria, éste!), M. Rouche, J. J. Sayas, etc.? ¿Que ellos tienden a lecturas distintas de las de uno? ¡Qué se le va a hacer! Pero lo que no procede bajo ningún concepto es afirmar que tantos autores de honestidad científica reconocida no hacen crítica de las fuentes de que se valen. Podrá decirse que su crítica no es acertada o que es insuficiente, y tratar de probarlo con argumentos pertinentes; pero no, que no la hagan.

Todo ello viene a cuento de que a Larrea no le parece serio en absoluto un procedimiento historiográfico en que se acumulan y "suman sin discriminación fragmentos de poesías con pasajes historiográficos y fragmentos epistolares" como "testimonios de una determinada situación social, cultural, religiosa o política". Por supuesto, que la acumulación de testimonios no es sinónimo de rigor. Mas las referencias textuales están en cualquier caso ahí, por muy necesitadas de tratamiento semiótico que se las estime, y ahí está también - para el caso de pasajes como los de Prudencio, Paulino o Venancio Fortunato- la historia posterior del área, necesitada también de iluminaciones o explicaciones en ese pasado más o menos cercano que la condiciona, y que, al ser tanta, por lo demás, la miseria de nuestras fuentes de información, empuja al estudioso a fijarse en testimonios de entidad tan endeble. Pero, como dicho, ${ }_{i}$ los textos están ahí!, y ise acumulan!, y icobran toda su importancia a la luz de esa historia posterior, sin la cual tal vez habrían pasado desapercibidos! Es decir, que testimonios que tomados uno a uno - cada cual en su estricta y endeble literalidad - serían posiblemente preteridos y tratados en clave de reminiscencias librescas o de ejercicio retórico, al acumularse, como al caso, en un momento determinado de un pueblo o una etnia que protagoniza una historia harto peculiar en la etapa siguiente, cobran una entidad significativa añadida en razón de esa acumulación -que cabría ya estimar sintomática- y de esa posterior historia, necesitada de iluminaciones o explicaciones en su proceso genético.

Porque a lo del inquietos Vasconas de F. Avieno -una interpolación que sólo a título de hipótesis (pero ¡verosímil, al fin y al cabo!) puede datarse a fines del s. IV - se añaden las palabras nada amables con que apostrofa Pru- 
dencio - ipoeta él! - a la bruta Vasconum gentilitas de antaño ${ }^{73}$; y los pasajes -ipuro ejercicio de retórica, sin duda! - en que Paulino ${ }^{74}$, desde la comodidad de su retiro contemplativo en alguna lujosa villa de Hispania, alude a la barbarie, incivilidad e inhumanidad de los Vascones de la montaña (como quiere J. J. Larrea ${ }^{75}$ ); y las referencias de la Notitia dignitatum a reajustes introducidos por la administración imperial en el dispositivo estratégico del área (reajustes, que puede que no tengan nada que ver con la instrumentación de un supuesto limes norhispánico ${ }^{76}$, pero cuya interpretación a la luz de otras hipótesis alternativas tampoco se libra de importantes reservas ${ }^{77}$, y que, en cualquier caso, ahí están como indicativos de un incremento de la presencia militar romana justo en las inmediaciones del territorio vascocántabro); y los textos hidacianos que a título hipotético - pero jverosímilmente también!- permiten situar en un ámbito vascón ciertos episodios de la bagaudia así llamada Tarraconense $^{78:}$ todo ello, en un período para el que los arqué́logos han señalado

$73 \mathrm{~V}$. cómo enjuicia los mismos - -y sin limitar, por cierto, su significado al vascón montañés o al del saltus., J. FONTAINE: Romanité et hispanité dans la littérature hispano-romaine des $V^{e}$ et ve siècles, in Assimilation et résistence à la culture gréco-romaine dans le monde ancien. Travaux du Vle Congrès International d'études classiques, Bucarest-Paris 1976., pp. 301-22, concret. 315-18; ID.: Société et culture chrétiennes sur l'aire circumpyrénéenne au siècle de Théodose, en "Bulletin de Littérature ecclesiastique" $75,1974,241-82$, concr. $260 \mathrm{~s}$.

74 Tiene razón quizá mi estimado colega en que no tenía por qué haber metido en este lio al mentor, amigo y paisano de Paulino, Ausonio. Pero ahí están, de todas formas, los vv. $50-53$ de su Epist. XXIX, en que hace responsables al salsus Vasconis y a los ninguida Pyrenaei hospitia del cambio que supuestamente se habría producido en las costumbres del dulcísimo Paulino.

75 De hecho, los textos - tanto el de Ausonio como el de Paulino- hacen entrar en juego no sólo a los ninguida Pyrenaei hospitia, sino también al saltus Vasconis, que no se ve por qué ha de limitarse en rigor al ámbito de montaña, pudiendo también entenderse por saltus el espacio boscoso no agrarizado y de fundamental dedicación ganadera de ciertos valles navarros al Norte de una línea imaginaria que pudiera tenderse de Jaca pasando por Pamplona hasta el límite de Alava (v. M. J. PEREX Agorreta: Los Vascones..., pp. 252-54). En una ocasión Paulino se refiere también con mayor generalidad a los confines vascónicos (Vasconicis [...) in oris - escribe en el v. 218 de la Epist. $X=$ Epist. $X X X I$ de Ausonio). Pero no creo que haya pasado por mi cabeza hacer extensivo a todos los Vascones - como parece achacarme Larrea (p. 325)- lo que dice Paulino referido a los que vivían in oris Vasconicis o en el saltus vascón.

76 V., por ej., J. ARCE: La "Notitia dignitatum" et l'armée romaine dans la "diocesis Hispaniarum", en "Chiron" 10, 1980, 593-608; ID.: El ultimo siglo de la España romana: 284-409, Madrid 1982, pp. 65-72 y Apéndice I, pp. 165-8; A. BALIL; recensión de la obra de J. Arce (Et último siglo...), en "BSEAA" 50, 1984, 493, etc.

77 V., por ej., J. J. SAYAS ABENGOECHEA: Consideraciones históricas sobre Vasconia en época bajoimperial (1984), en ID.: Los Vascos..., pp. 325-67, concr. 328-335.

$78 \mathrm{~V}$. al respecto K. LARRAN̄AGA ELORZA: Un tema controvertido: la relación entre los Vascones y la ast llamada Bagaudia Tarraconense, en II Congreso General de Historia de Navarra, Pamplona-Estella 24-28 septiembre de 1990, en "Príncipe de Viana" 53, Anejo 14 - 1992, pp. 229-241.

Medievalia Hispanica Hispania Sacra $50(1998)$ 
fenómenos de reviviscencia del trogloditismo ${ }^{79}$, y algún caso de pillaje e incendio de villa urban $\mathrm{a}^{80} . \mathrm{Y}$, tras un siglo de silencio, testigo de la nuina definitiva del Imperio de Occidente, de la caída del reino visigodo de Tolosa y de los azarosos comienzos del de Toledo, los pasajes — iretóricos, sin duda! — de Venancio Fortunato, y lo demás. No se trata de sumar sin discriminación -duro reproche- "fragmentos de poesías con pasajes historiográficos y fragmentos epistolares". Uno - que no es ningún experto en materia de crítica literaria, y puede por lo mismo errar, como afirma sin vacilación Larrea haberlo hecho quien esto suscribe- ha tenido, con todo, la preocupación mínima de informarse de lo que otros -especialistas de historia literaria, en algún caso- piensan de tales textos y de sus autores, tras "analizar —como postula Larrea- sus métodos, sus fuentes, sus referentes, sus juegos literarios, [etc., etc.]". Lo que pasa es que los textos se suman ellos - valga la perogrullada-, al ofrecerse tal cual a la atención del estudioso que busca claves para entender ciertos procesos de la historia inmediatamente posterior. Y lo que pasa es que, al sumarse los testimonios y al retroproyectar esa inmediata historia posterior sus luces (o exigencia de luces) a lo acontecido con anterioridad, el estudioso empieza a sospechar vehementemente de si es lícito achacarlo todo a códigos y juegos literarios. Y, por cierto, no tiene por qué pensar mi estimado colega en ocultas intenciones, para explicarse el hecho de que se haya silenciado lo que, al parecer, debía haberse sabido desde la edición de las obras de Paulino por Hartel en 1894: sencillamente, a uno puede por descuido habérsele pasado por alto la erudita referencia del editor al subyacente texto de Horacio; o puede también que uno, que la conoce, haya con todo estimado que ello no es en sí mismo un óbice para concluir que, a despecho de remedos y juegos literarios, el texto no deja de ser menos testimonio de algo real o percibido como tal, según dan a entender otros varios indicios convergentes y la posterior historia del área. A no ser, claro está, que lo de la convergencia de indicios o testimonios obedezca a un puro efecto dominó, que hace que lo que un eximio miembro de la clase senatorial romana escribió, tocado de la manía de hablar y urgido por las rigideces del exámetro, cualquier lunes por la mañana, venga repitiéndose como en ecos a través de generaciones de escolares que no saben, por lo visto, hacer otra cosa que copiar o glosar lo que dijeron sus maestros.

En este punto, Larrea, informado, sin duda, por los cientos de trabajos que "desde hace muchos años — dice- han dedicado filólogos e historiadores de

79 Cfr. J. M. APELLÁniz: El Grupo de Santimamiñe durante la Prehistoria con cerámica, in "Munibe" 27, 1975, 1-136, concr. pp. 83-86; ID.: El Grupo de Los Husos durante la Prehistoria con cerámica en el País Vasco, in "EAA" 7, 1974, 7-409, concr. pp. 356-62; A. GONZÄLEZ BLANCO, U. ESPINOSA, J. M. SÁENZ: La población de la Rioja durante los siglos obscuros (IV-X), en "Berceo" $n$. $96,1979,81-111$.

$80 \mathrm{~V}$. infra referencias de la nota 87.

Medievalia Hispanica

Hispania Sacra 50 (1998) 
la literatura a analizar los métodos, fuentes, referentes, juegos literarios, vocabulario, intereses, visión del munđo, biografias" de los autores analizados ${ }^{81}$, desarrolla una lección magistral sobre cómo han de ser entendidos sus textos, para concluir que en los versos referidos a la inhumanidad y ferocidad de los bandoleros vascones del saltus pirenaico, Paulino está de hecho remedando un pasaje de Horacio; que en el poema "los vascones del Pirineo no son más que el pretexto para desarrollar un juego literario entre antiguo alumno y maestro"; y que es harto dudoso, "no ya que [Paulino] vea en el estado de los vascones del Pirineo un problema, sino simplemente que le interesen lo más mínimo, a él como a Ausonio".

Vaya por delante que el tema resulta más bien puntual en nuestro caso, y que, si me detengo en él, es porque mi estimado colega lo ha singularizado -a efectos didácticos o, como se expresa, a título de "somero ejemplo"- - Hecha esa salvedad, añadiré que uno (que no puede desde luego presumir de haber leído esos cientos de trabajos a que se remite mi colega, y que en su poquedad se ha limitado a consultar alguno que otro de ellos) tiene, empero, sus dudas sobre que las cosas resulten tan sencillas. En primer lugar, no puede uno sino recordar que la misma epístola en que se hallan las referencias a los Vascones del saltus contiene otras expresiones bien explícitas en que un Paulino, tocado por la luz del Evangelio y decidido a entregarse a la ascesis cristiana, se diría renegar de las musas y vaciedades de la literatura de ficción, para no servir sino a lo único necesario ${ }^{82}$. Está, luego, que, si a Ausonio y Paulino no preocupan lo más mínimo los Vascones del saltus -como parece saber de buena tinta mi estimado colega -, no es la misma a la sazón la actitud de la administración imperial (de la que, según es sabido, fueron aquéllos por algun tiempo leales servidores...) respecto de comunidades de montaña, que desarrollan formas culturales como las que cabe verosímilmente atribuir a los Vascones pirenaicos, citados por el poeta: es un hecho, cuando menos, que en una constitución del emperador Honorio del año 409 los pastores son asimilados pura y simplemente a los bandoleros ${ }^{83}$ (fenómeno de asimilación, que hace pensar que

81 O. c., pp. $325 \mathrm{~s}$.

82 Epist. X (AuSONII XXXI), vv. 33-42: “Vacare uanis, otio aut negotio / Et fabulosis litteris / Vetat [el Dios cristiano], suis ut pareamus legimus / Lucemque cemamus suam, / Quam uis sophorum callida arsque thetorum et / Figmenta uatum nubilant, / Qui corda falsis atque uanis imbuunt /Tantumque linguas instruunt: / Nihil adferentes, ut salutem conferant, / Quod ueritatem detegat".

83 Cod. Theod, 9, 31, 1. En la misma se prohibe la entrega de neonatos a los pastores para su nutrición, so pena de que los contraventores sean estimados como cómplices de los latrones. ("societatem latronum videbitur confiteri"). Hay otra constitución de los emperadores Valentiniano, Teodosio y Arcadio (CIL I 55, 6), del 392 (e. d., de allá por los años en que Paulino escribe su epíst. X), que revela también la honda preocupación que causa a la administración imperial el recrudecimiento de la plaga del bandolerismo en ciertas regiones, fenomeno de recrudecimiento que le obliga a dictar enér- 
en los difíciles momentos por que atraviesa el Imperio desde las postrimerías del s. IV se agudiza el problema que representa tradicionalmente para la administración romana la presencia de colectivos humanos que, por su régimen de trashumancia y los entornos en que se mueven, le resultan de hecho prácticamente incontrolables, sobre todo cuando se aflojan, como en el Tardo Imperio, los mecanismos de acción del Estado ${ }^{84}$ ). No hay que olvidar, en fin, que las expresiones de Paulino, no obstante cuanto se diga sobre su carácter retórico ${ }^{85}$, constituyen uno más de una serie de indicios confluyentes, que, según notábamos más arriba, hallan su más plena interpretación en el cuadro de la historia ulterior del área ${ }^{86}$. Y que en el entorno pirenaico aludido por Ausonio y Paulino se producían situaciones susceptibles de provocar la alarma de las clases pudientes del Tardo Imperio, lo sugiere a su modo el hecho del pillaje e incendio a que fueron sometidos hacia finales del s. IV tanto la villa de Montmaurin, como el santuario termal —próximo a la misma— de "La Hillère"87.

gicas medidas, para imponer un freno al creciente número de crímenes que quedaban impunes (Per omnes regiones, in quibus fera et periculi sui nescia latronum fervet insania, probatissimi quigue et districtissimi defensores adsint disciplinae et quotidianis actibus praesint, qui non sinant crimina impunita coalescere, etc.). Es sabido que en el área se documenta un texto epigráfico, aunque de problemática datación (CIL II 2968), que evidencia la presencia de latrones en tierras vascónicas.

84 Cfr. A. GIARDINA; Uomini e spazi aperti, en A. SCHIAvone (dir.): Storia di Roma, v. IV: Caratteri e morfologie, Torino 1989 , pp. 71-99, concr. $83 \mathrm{~s}$. Llama la atención del autor "l'immediata e meccanica assimilazione" que se hace en la constitucion imperial entre pastores y latrones, asimilación -prosigue- "che marca, almeno nella prospettiva del potere imperiale, l'avvenuto distacco tra forme d'insediamento inserite in contesti propriamente agricoli, e quindi relativamente controllabili, e forme che sfugono al controllo perchè tipiche di percorsi e ambienti (gli spazi aperti dei saltus, gli itinerari dei calles) su cui il potere aveve una presa cronicamente debole o addirittura inesistente".

8s Cabría anotar aquí lo que A. GIARDINA, en el trabajo citado supra y comentando un pasaje del $D e$ rebus bellicis (6. 1-3), recuerda, a saber: que, a despecho de que puedan encontrárseles antecedentes y paralelos a ciertos textos, no por eso se sigue que estén privos de todo connotado con la realidad coetanea, porque "i topoi hanno spesso una vita autonoma" (p. 73). Ahora bien, las razones por las que el vascón del saluus se convierte, según sospecho, en motivo de inquietud hacia fines del s. IV, puede que hayan de buscarse en la dirección apuntada por el autor. De hecho, el desarrollo pleno de modelos romanos de propiedad del suelo y la agrarización intensiva del llano suponen en muchas partes del Imperio la quiebra de antiguos equilibrios económicos basados en el régimen de trashumancia o, en todo caso, en una relación de complementariedad llanura-montaña, quiebra que puede resultar un impulso decisivo hacia la marginalización de los grupos humanos integrados antes en tales equilibrios (v. o. c., pp. 78-84).

${ }^{86}$ ¿Se ha reparado en el uso que hace Paulino del término barbarus, referido a los Vascones del saltus, término que, a esas alturas del siglo y en la pluma de los autores cristianos, va cobrando, como se sabe, connotaciones sensiblemente diferentes de las que tuvo otrora, para acabar significando al que se mueve al margen del mundo romano-cristiano? V. al respecto L. GRACCO RUGGINI: Culture in dialogo: la preistoria dellidea di Europa. en A. SCHIAvONE (dir.): Storia di Roma, v. III: L'età tardoantica, I: Crisi e trasformazioni., Torino 1993, pp. 351-367, concr. pp. 364s.

87 Cfr. G. FouET: Le sanctuaire des eaux de "La Hillère" a Montmaurin (H.-G.), in "Gallia" 30, 1972, 83-126, concr. pp. 122s.

Medievalia Hispanica

Hispania Sacra S0 (1998) 